\title{
Interdigital Tinea Nigra
}

\author{
Marina K. Ibraheim ${ }^{1}$, Michelle A. McNally ${ }^{1}$, Jaime Tschen ${ }^{2}$ \\ 1. Dermatology, John P. and Kathrine G. McGovern School of Medicine, University of Texas Health Center, Houston, \\ USA 2. Dermatology, St. Joseph Dermatopathology, Houston, USA
}

Corresponding author: Marina K. Ibraheim, marina.k.ibraheim@uth.tmc.edu

\begin{abstract}
Tinea nigra is an uncommon superficial dermatomycosis precipitated by Hortaea werneckii, a halophilic and halothermic yeast-like fungus capable of producing a melanin-like substance. This pathogen infiltrates the stratum corneum in the setting of microtrauma and produces an asymptomatic brown to black macule or patch that appears similarly to melanocytic nevi or melanoma. We present a case of a 52-year-old woman who presented to clinic several months after developing a painless, nonpruritic dark brown patch in her left foot inside the fourth toe web. The coloration and location of this lesion would typically prompt biopsy; however, Wood's lamp examination and potassium hydroxide $(\mathrm{KOH})$ preparation were pursued first and demonstrated evidence of infection by $H$. werneckii. The patient was treated with topical clotrimazole cream and miconazole powder for one month, and her lesions cleared completely. Her lesions did not recur at her three-month follow-up appointment.
\end{abstract}

Categories: Dermatology, Infectious Disease

Keywords: tinea nigra, interdigital, dermatomycosis, koh preparation

\section{Introduction}

Tinea nigra is a superficial dermatomycosis precipitated by Hortaea werneckii, a melanized yeast-like fungus formerly classified in the literature as Exophiala, Phaeoannellomyces, and Cladosporium [1]. This pathogen thrives in high-temperature, low-oxygen, and humid environments, affecting individuals in temperate or subtropical climates $[1,2]$. For this reason, palmoplantar hyperhidrosis significantly predisposes to the development of tinea nigra [1].

Patients present with asymptomatic, unilateral, enlarging, well-demarcated, brown to black macules with irregular borders on the palms or soles [1]. The lesions appear grossly similar to melanocytic lesions [3]. Utilization of KOH preparation, Wood's lamp, and dermoscopy can distinguish between these two diseases [4]. We present a woman with interdigital tinea nigra without a prior history of melanoma; $\mathrm{KOH}$ testing prevented unnecessary biopsy.

Received 03/24/2020 Review began 03/30/2020 Review ended 04/06/2020 Published 04/07/2020

○ Copyright 2020 Ibraheim et al. This is an open access article distributed under the terms of the Creative Commons Attribution License CC-BY 4.0., which permits unrestricted use, distribution, and reproduction in any medium, provided the original author and source are credited.

\section{Case Presentation}

A 52-year-old woman presented several months after developing a painless, nonpruritic dark brown patch in her left foot inside the fourth toe web. She had never developed a lesion of this nature before. The patient's past medical history was significant for lentigos, angiomas, and basal cell carcinoma on the nose treated two years earlier. No family members or close contacts had developed these lesions.

Physical exam revealed a brown irregular patch in her left fourth toe web (Figure $1 \mathrm{~A}$ ). Wood's light examination showed a green fluorescence over the area (Figure 1B). 


\section{Cureus}
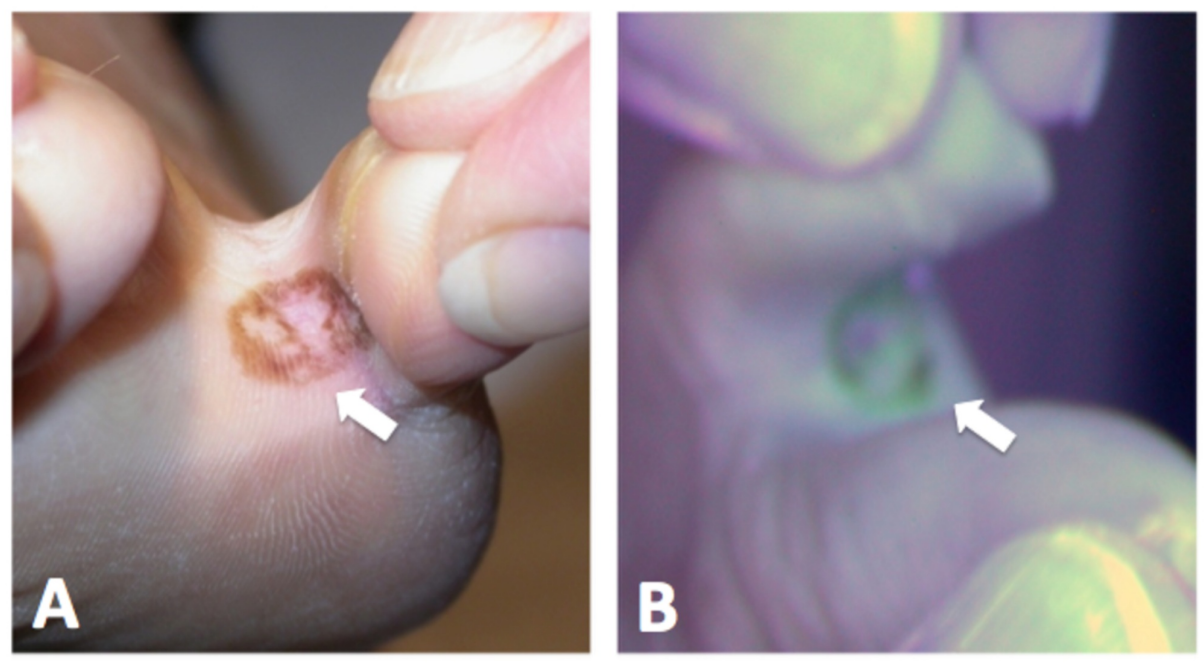

\section{FIGURE 1: Irregular pigmented patch visualized grossly and under}

Wood's light

(A) Brown irregular patch in the left fourth toe web. (B) Lesion fluorescing green under Wood's light.

A KOH examination of scrapings showed colonies of brown fungi both in spores and hyphae (Figure 2).
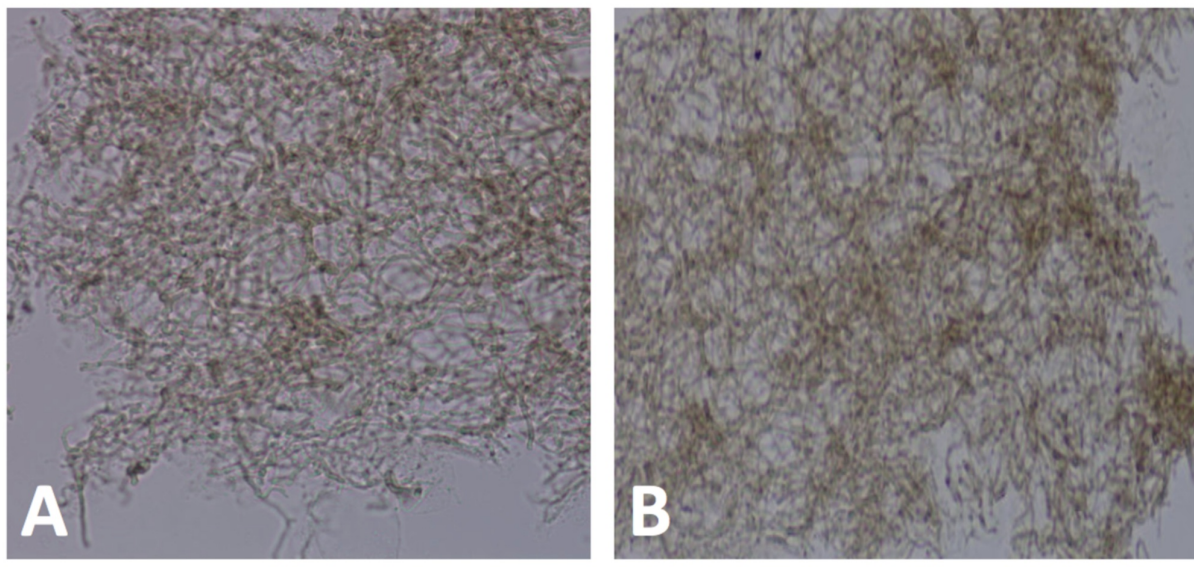

\section{FIGURE 2: KOH scraping of lesion}

(A) From $\mathrm{KOH}$ preparation, we can see colonies of brown, septating, branching hyphae with spores. (B) Closer view.

The patient was instructed to utilize clotrimazole cream and miconazole powder for one month. After onemonth follow-up, her lesion resolved; after three-month follow-up, her lesions did not recur.

\section{Discussion}

Tinea nigra develops when $H$. werneckii inoculates the stratum corneum in the setting of microtrauma and incubates for two to seven weeks. The fungus thrives in the humidity and has affected individuals living in tropical and subtropical areas, such as Mexico, Venezuela, Chile, Brazil, India, Japan, and Panama [1,5-9]. Cases reported in the United States occur infrequently. Cases have been reported in North Carolina, South Carolina, Texas, and Florida [9-11]. Texas and Florida in particular harbor more humid environments, which enable fungal growth.

Once the fungus has infiltrated the lipid-rich, warm, and humid environment of the stratum corneum, $H$. werneckii proliferates and develops a melanin-like substance within itself [12]. The pigmented lesion seen with tinea nigra often appears similar to melanocytic nevi or melanoma $[3,12]$. The patient's recent history of skin cancer prompted concern for the presence of another malignancy. The location of the patient's lesion in this case further complicates matters, as tinea nigra classically appears on palmoplantar surfaces. 
Interdigital infiltration occurs infrequently [1]. Given this uncommon presentation, pigmented macular lesions like this may warrant a biopsy; however, biopsies are invasive, distressing, and results take time to return. Utilization of noninvasive modalities of testing such as dermoscopy and $\mathrm{KOH}$ preparation can aid in prompt diagnosis. Dermoscopic examination would show wispy brown strands, or pigmented spicules that do not follow dermatoglyphic furrows and ridges [13]. KOH preparation would reveal brown, septate hyphae, consistent with what was seen in this case [3].

Topical keratinolytic and antifungal agents are typically utilized to treat tinea nigra; hence, there is no need for systemic therapy. Remedies include undecylenic acid, Whitfield's ointment, retinoic acid, ketoconazole, itraconazole, clotrimazole, or miconazole [12]. In our case, the combination of clotrimazole cream and miconazole powder was cost-effective and efficacious in Houston's humid climate. The infection resolves within two weeks to a month after treatment and typically does not recur $[1,3,12]$.

\section{Conclusions}

Tinea nigra is an uncommon dermatomycosis typically presenting on palmoplantar surfaces of the body and rarely occurs on interdigital surfaces. $H$. werneckii, the underlying fungus, develops a melanin-like substance in the stratum corneum, resulting in the development of asymptomatic brown macules and patches with irregular borders. These pigmented lesions are concerning for melanocytic nevi or melanoma. This case highlights the concern and importance in differentiating $H$. werneckii from melanoma, especially in patients with a past history of skin cancer. While biopsy can aid in diagnosis, Wood's lamp and KOH preparation can allow for efficient and noninvasive assessment of a pigmented lesion.

\section{Additional Information \\ Disclosures}

Human subjects: Consent was obtained by all participants in this study. Conflicts of interest: In compliance with the ICMJE uniform disclosure form, all authors declare the following: Payment/services info: All authors have declared that no financial support was received from any organization for the submitted work. Financial relationships: All authors have declared that they have no financial relationships at present or within the previous three years with any organizations that might have an interest in the submitted work. Other relationships: All authors have declared that there are no other relationships or activities that could appear to have influenced the submitted work.

\section{References}

1. Bonifaz A, Badali H, de Hoog GS, et al.: Tinea nigra by Hortaea werneckii, a report of 22 cases from Mexico . Stud Mycol. 2008, 61:77-82. 10.3114/sim.2008.61.07

2. Elsayed A, Mowafy AM, Soliman HM, Gebreil A, Magdy NI: Characterization of new strains of Hortaea werneckii isolated from salt marshes of Egypt. Egypt J Basic Appl Sci. 2019, 3:350-356. 10.1016/j.ejbas.2016.09.001

3. Falcão EM, Trope BM, Martins NR, Barreiros Mda G, Ramos-E-Silva M: Bilateral tinea nigra plantaris with good response to isoconazole cream: a case report. Case Rep Dermatol. 2015, 7:306-310. 10.1159/000441602

4. Criado PR, Delgado L, Pereira GA: Dermoscopy revealing a case of tinea nigra . An Bras Dermatol. 2013, 88:128-129. 10.1590/s0365-05962013000100021

5. Severo LC, Bassanesi MC, Londero AT: Tinea nigra: report of four cases observed in Rio Grande do Sul (Brazil) and a review of Brazilian literature. Mycopathologia. 1993, 126:157-162. https://doi.org/10.1007/BF01103769

6. Perez C, Colella MT, Olaizola C, de Capriles CH, Magaldi S, Mata-Essayag S: Tinea nigra: report of twelve cases in Venezuela. Mycopathologia. 2005, 160:235-238. https://doi.org/10.1007/s11046-005-2888-7

7. Cabrera R, Sabatin N, Urrutia M, Sepulveda R: Tinea nigra: a allochthonous case report in Chile . Mycopathologia. 2013, 30:90-93. https://doi.org/10.4067/S0716-10182013000100016

8. Uezato H, Gushi M., Hagiwara K, Kayo S, Hosokawa A, Nonaka S: A case of tinea nigra palmaris in Okinawa, Japan. J Dermatol. 2006, 33:23-29. https://doi.org/10.1111/j.1346-8138.2006.00004.x

9. Sarangi G, Dash D, Chayani N, Patjoshi SK, Jena S: Bilateral tinea nigra of palm: a rare case report from Eastern India. Indian J Med Microbiol. 2014, 32:86. 10.4103/0255-0857.124336

10. Ritchie EB, Pinkerton ME: A case of tinea nigra palmaris in Texas . AMA Arch Derm. 1955, 72:467-468. 10.1001/archderm.1955.03730350069013

11. Van Velsor H, Singletary H: Tinea nigra palmaris: a report of 15 cases from coastal North Carolina . Arch Dermatol. 1964, 90:59-61. 10.1001/archderm.1964.01600010065013

12. Schwartz RA: Superficial fungal infections. Lancet. 2004, 364:1173-1182. https://doi.org/10.1016/S01406736(04)17107-9

13. Abinader MVM, Maron SMC, Araújo LO, Silva A do A: Tinea nigra dermoscopy: a useful assessment . J Am Acad Dermatol. 2016, 74:e121-e122. 10.1016/j.jaad.2015.12.016 